Article

\title{
Exosomal miR-92a Concentration in the Serum of Shift Workers
}

\author{
Massimo Bracci ${ }^{1, *(\mathbb{D}}$, Maria Eléxpuru Zabaleta ${ }^{1} \mathbb{D}$, Maria Fiorella Tartaglione ${ }^{1}$, \\ Caterina Ledda ${ }^{2}$, Venerando Rapisarda ${ }^{2}$ and Lory Santarelli ${ }^{1}$ (i) \\ 1 Department of Clinical and Molecular Sciences, Polytechnic University of Marche, 60126 Ancona, Italy; \\ mariaelexpuru@gmail.com (M.E.Z.); m.f.tartaglione@pm.univpm.it (M.F.T.); 1.santarelli@univpm.it (L.S.) \\ 2 Department of Clinical and Experimental Medicine, University of Catania, 95124 Catania, Italy; \\ cledda@unict.it (C.L.); vrapisarda@unict.it (V.R.) \\ * Correspondence: m.bracci@univpm.it; Tel.: +39-071-220-6063; Fax: +39-071-220-6062
}

Received: 12 December 2019; Accepted: 31 December 2019; Published: 7 January 2020

\begin{abstract}
Shift work is associated with alterations in the human biological clock and metabolism. Serum exosomal miR-92a concentration was inversely correlated with brown adipose tissue activity playing a pivotal role in energy balance. In this study, miR-92a was measured in serum exosomes of 30 workers engaged in shift and daytime work. No significant metabolic alterations were shown between daytime and shift workers while a difference in serum exosomal miR-92a levels was found between the two groups. The lower levels of miR-92a in shift workers were suggestive of a higher brown adipose tissue activity compared with daytime workers. However, the possibility that other physiological and pathological processes may influence miR-92a cannot be ruled out. Our results suggest further investigations on brown adipose tissue activity and on miR-92a regulatory mechanisms, such as those related to the estrogen pathway, in shift workers.
\end{abstract}

Keywords: shift work; night work; circadian disruption; metabolism; metabolic syndrome; brown adipose tissue; BAT activity; miR-92a

\section{Introduction}

Working on a shift work schedule implies that some daily habits, such as sleeping or eating, are not conducted with regular occurrence [1] resulting in a possible desynchronization between external and biological times [2]. The perturbation of the biological clock leads to alterations of several metabolic processes including reduced glucose tolerance, dislipydemia, weight gain [2-4], and the impairment of some molecules related to fat absorption and metabolism [2,5]. Epidemiological studies associated shift work with an increased incidence of metabolic syndrome [6,7] that, in turn, is an important cardiovascular risk factor [8,9]. Since alterations of metabolic parameters and weight gain in shift workers do not seem to be associated with low physical activity or increased food intake [5,10], it is likely that there are other factors that may influence energy balance.

In the last few decades, brown adipose tissue (BAT) has regained scientific and public interest for its role in metabolism and weight gain [11-16]. BAT is a rich vascularized tissue with a high number of mitochondria. It catabolizes lipids to generate heat playing a major role in thermogenesis and energy expenditure [17-20]. Similar to lipids, BAT also metabolizes carbohydrates, contributing to the homeostasis of these two groups of macromolecules resulting in a beneficial effect on overall metabolism [21-23]. Obese patients have less active BAT [24]. In fact, an inverse relationship between active BAT and body mass index (BMI) has been discovered [25].

The most used method for quantitatively measuring BAT volume and activity is the ${ }^{18}$ fluor-deoxyglucose positron emission tomography coupled with computed tomography (FDG-PET/CT) [11]. Since 
this method is costly, labor-intensive, and involves exposure to radiation, some parameters were recently studied as biomarkers of BAT activity.

MiRNAs are small, non-coding RNAs which regulate protein expression in several tissues [26-28]. MiRNAs are molecules that complementary bind mRNA and downregulate gene expression by translational repression, mRNA cleavage, and deadenylation [29]. MiRNAs are carried by exosomes, which are small lipid vesicles $(40-100 \mathrm{~nm}$ in size) that constitute cell-to-cell communication [30,31]. Exosomes allow an exchange of material between cells in an autocrine, paracrine, and even endocrine manner [32,33]. MiRNAs present in human blood are stable and they are resistant to endogenous RNase activity [34]. MiRNAs are involved in the regulation of several pathological processes and represent new diagnostic and prognostic biomarkers for the diagnosis of various diseases [35]. Several miRNAs have proven to play a major role in BAT, such as controlling brown adipocytes differentiation [36]. Among these miRNAs, miR-92a has been involved in several metabolic processes, such as glucose homeostasis [24], regulation of intracellular cholesterol levels [37], and essential hypertension [38]. Furthermore, Chen and collaborators demonstrated that serum levels of exosomal miR-92a were inversely correlated with human BAT activity, confirming the data by FDG-PET/CT [39]. Due to miR-92a in serum exosomes can easily be assessed, it could be considered a non-invasive biomarker for BAT activity [39].

In light of this information, it was decided to study the levels of miR-92a in shift and daytime workers.

\section{Materials and Methods}

\subsection{Subjetct Enrollment}

The concentration of exosomal miR-92a was determined in the serum of 30 workers enrolled among the nursing staff of Area Vasta 2 (Ancona, Italy). All nurses were female, fifteen subjects worked a rotating shift schedule that included night shifts (SW nurses), whereas the other 15 workers were involved exclusively in daytime shifts (DT nurses).

Selection criteria were the following: fertile age; no current use ofmedications; a negative history of psychiatric disorders, insomnia, cancer or chronic systemic diseases, such as degenerative, cardiovascular or autoimmune disorders; absence of artificial light when sleeping at home; no occupational tasks involving exposure to ionizing radiation or antiblastic drugs. SW nurses had to be enrolled in the current shift schedule, including more than 60 night shifts/year, for more than 2 years without schedule breaks in the previous 6 months. DT nurses had to go to bed habitually around 23:00 and to wake up around 06:00 without sleepless nights for more than 3 weeks prior to the study.

Workers provided their consent after receiving information about the purpose and procedures of the study, which was conducted according to the Helsinki Statement of Ethical Standards. Being performed as part of required, routine health surveillance, the study required no formal approval by the local ethics committee. The SW nurses worked a fast clockwise shift schedule: day 1, 07:00-14:00; day 2, 14:00-22:00; day 3, 22:00-07:00; rest for $48 \mathrm{~h}$; resumption of the cycle. The DT nurses worked from 07:00 to 14:00 for 6 days/week. To exclude the acute alterations related to night shift, fasting venous blood samples were taken from both SW and DT nurses at the beginning of the morning shift after a regular night's sleep on a day off. Blood samples were processed immediately after collection. An aliquot of serum was stored at $-80^{\circ} \mathrm{C}$ until miR-92a analysis. Blood was analyzed the same day for glycemia, total and HDL cholesterol, and triglycerides.

\subsection{Clinical Parameters Collection}

Socio-demographic characteristics were collected as part of the medical history. The chronotype was investigated by the "Morningness-Eveningness Questionnaire" (MEQ) [40], a questionnaire with 19 items and a total score ranging from 16 to 86 , widely used in adults and workers [41-44]. Sleep quality was investigated using the Pittsburgh Sleep Quality Index (PSQI) [45], while daytime sleepiness was 
assessed by the Epworth Sleepiness Scale (ESS) [46,47]. Measurement of anthropometric parameters was performed during the medical examination. The fat mass was calculated using Durnin and Womersley formula [48]. A food diary was kept by workers for 5 consecutive days and daily average values of total energy intake and fat, carbohydrate, and protein intake were calculated [49]. Daily average values of total energy expenditure and energy expenditure due to motor activity were investigated using a metabolic monitor (SenseWear Armband ${ }^{\circledR}$; BodyMedia Inc., Pittsburgh, PA, USA) [50], secured on each participant's right arm for 5 days. There were no cases of interrupted or invalid recordings.

\subsection{Determination of Serum Exosomal miR-92a}

Serum exosomal miR-92a was measured after a few months in storage at $-80^{\circ} \mathrm{C}$. Samples of $\mathrm{SW}$ and DT nurses were coded in a mixed order and analyzed by blinded personnel. After all the samples completed the miRNAs extraction, they underwent the reverse transcription and finally the relative qRT-PCR. The determination of serum exosomal miR-92a was completed in about two months.

\subsubsection{MiRNAs Extraction}

Exosomes were extracted from $1 \mathrm{~mL}$ of serum using a "Total Exosome Isolation (from serum)" Kit (Invitrogen; Thermo Fisher Scientific, Inc., Waltham, MA, USA) according to the manufacturer's instructions. Exosomal proteins were then quantified through the Bradford method and $20 \mu \mathrm{g}$ of exosomal protein were diluted in $250 \mu \mathrm{L}$ of PBS for the following RNA extraction process. We used the same quantity of exosomal protein to prevent differences in miR-92a related to the total amount of exosomes. Before RNA isolation, and to avoid further technical errors during the subsequent quantification of miRNAs by qRT-PCR, $60 \mathrm{fmol}$ of a synthetic spike-in small RNA from Caenorhabditis elegans (cel-miR-39) were added to the samples as external normalizer [51]. Total RNA was then extracted by adding $750 \mu \mathrm{L}$ of Tri-Reagent BD (Sigma-Aldrich, Saint Louis, MO, USA) and $200 \mu \mathrm{L}$ of chloroform. The Phase Lock Gel (Eppendorf, Hamburg, Germany) was used to enhance the phase separation. Finally, miRNAs were isolated using the Purelink miRNA Isolation Kit (Invitrogen; Thermo Fisher Scientific, Inc.) and eluted in a final volume of $40 \mu \mathrm{L}$ of RNase-free water, centrifuging twice $20 \mu \mathrm{L}$ to improve the yield. Samples were stored at $-80^{\circ} \mathrm{C}$ until reverse transcription.

\subsubsection{Reverse Transcription}

Reverse transcription reactions were performed using a High Capacity cDNA Reverse Transcription Kit (Applied Biosystems; Thermo Fisher Scientific, Inc., Waltham, MA, USA) with miRNA-specific stem-loop primers: small nuclear RNA U6 (Applied Biosystems, \#RT: 001973), cel-miR-39 (Applied Biosystems, \#RT: 000200), and miR-92a (Applied Biosystems, \#RT: 000431). The $7.5 \mu \mathrm{L}$ volume reaction was as follows: $5.5 \mu \mathrm{L}$ of master mix $\left(2.58 \mu \mathrm{L} \mathrm{H} \mathrm{H}_{2} \mathrm{O}, 0.75 \mu \mathrm{L} 10 \times\right.$ reverse-transcription buffer, $0.095 \mu \mathrm{L}$ RNase-inhibitor $(20 \mathrm{U} / \mu \mathrm{L}), 0.075 \mu \mathrm{L}$ dNTPs $(100 \mathrm{mM}), 1.5 \mu \mathrm{L}$ RT primers, and $0.5 \mu \mathrm{L}$ reverse transcriptase) and $2 \mu \mathrm{L}$ of input miRNAs. Reverse transcription reactions were carried out on the Biometra thermal cycler (Analytik Jena AG, Jena, Germany) following these conditions: $16^{\circ} \mathrm{C}$ for $30 \mathrm{~min}, 42^{\circ} \mathrm{C}$ for $30 \mathrm{~min}, 85^{\circ} \mathrm{C}$ for $5 \mathrm{~min}$, and then held at $4{ }^{\circ} \mathrm{C}$. The reverse transcription products were stored at $-20^{\circ} \mathrm{C}$ until relative qRT-PCR.

\subsubsection{Relative qRT-PCR}

The qRT reactions were performed in duplicate in a final volume of $10 \mu \mathrm{L}: 5 \mu \mathrm{L}$ of MasterMix FluoCycle II ${ }^{\mathrm{TM}}$ Master Mix for Probe (Euroclone S.p.A., Pero, Italy) was mixed with $0.5 \mu \mathrm{L}$ of miRNA specific primer/probe mix small nuclear RNA U6 (Applied Biosystems, \#TM:001973), cel-miR-39 (Applied Biosystems, \#TM: 000200), and miR-92a (Applied Biosystems, \#TM: 000200)) and $1.33 \mu \mathrm{L}$ of cDNA into RNase-free strip-tubes sealed with their own flat cap (Eppendorf, Hamburg, Germany).The qRT-PCR reactions were run using the Realplex Mastercycler ep gradient S (Eppendorf, Hamburg, Germany) with the following thermal profile: $50^{\circ} \mathrm{C}$ for $2 \mathrm{~min}, 95^{\circ} \mathrm{C}$ for $10 \mathrm{~min}$, followed by 40 cycles of $95{ }^{\circ} \mathrm{C}$ for $15 \mathrm{~s}$ and $60^{\circ} \mathrm{C}$ for $1 \mathrm{~min}$. Finally, the temperature was held at $4{ }^{\circ} \mathrm{C}$. 
Data was normalized for biological variability, using the small nuclear RNA U6, and for possible technical variations during miRNAs extraction, using the cel-miR-39 as the exogenous normalizer. After the reaction was run, $\mathrm{Ct}$ values were determined and the relative quantification of miR-92a was calculated using the comparative $2^{-\Delta C t}$ method [52]. The expression of miR-92a was calculated by double normalization: Both controls (CtU6 and Ctcel-miR-39) were subtracted from the $\mathrm{Ct}$ value of the sample of interest [51-53].

\subsection{Statistical Analysis}

Kolmogorov-Smirnov test was used to assess the normality of distribution. Since miR-92a values were not normally distributed, a non-parametric statistical approach was chosen. Continuous variables were expressed as median (25th-75th percentile) and differences between DT and SW nurses were analyzed by Mann-Whitney U test. Dichotomous or categorical variables were expressed as percentages and differences were analyzed by Chi-square test. All the tests were two-tailed considering a $p<0.05$ as statistically significant. Data analysis was performed with the Statistical Package for Social Sciences version 19.0 (SPSS Inc., Chicago, IL, USA).

\section{Results}

All the workers who participated in the study were females. No significant differences were found in age, job seniority, numbers of smokers, or of alcohol drinkers between DT and SW nurses (Table 1). None of the SW nurses had changed the type of schedule from the beginning of the work as evidenced by the same values of job seniority and shift work seniority. SW nurses worked a median of 6.0 nights per month. No significant difference was found in chronotype (MEQ score), sleep quality (PSQI score), and daytime sleepiness (ESS score) between DT and SW nurses.

Table 1. Socio-demographic characteristics of daytime (DT) and shift-working (SW) nurses. MEQ: Morningness-Eveningness Questionnaire; PSQI: Pittsburgh Sleep Quality Index; ESS: Epworth Sleepiness Scale.

\begin{tabular}{lcc}
\hline & DT Nurses & SW Nurses \\
\hline $\begin{array}{l}\text { Age (years): } \\
\text { Median (25th-75th percentile) }\end{array}$ & $39.0(37.0-41.5)$ & $39.0(35.5-40.5)$ \\
\hline $\begin{array}{l}\text { Job seniority (years): } \\
\text { Median (25th-75th percentile) }\end{array}$ & $14.0(11.0-18.3)$ & $13.0(10.5-16.5)$ \\
\hline $\begin{array}{l}\text { Shift work seniority (years): } \\
\text { Median (25th-75th percentile) }\end{array}$ & - & $13.0(10.5-16.5)$ \\
\hline $\begin{array}{l}\text { Night worked per month: } \\
\text { Median (25th-75th percentile) }\end{array}$ & 40.0 & $6.0(5.3-6.0)$ \\
\hline Smokers (\%) & 43.3 & 40.0 \\
\hline Alcohol drinkers (\%) & $2.0(1.0-3.0)$ & $2.0(1.5-3.0)$ \\
\hline Subjects taking physical exercise (\%) & $57.5(52.5-64.0)$ & $57.0(51.3-62.0)$ \\
\hline Coffee consumption (cups/day): Median (25th-75th percentile) & 60.0 \\
\hline $\begin{array}{l}\text { Chronotype (MEQ score): } \\
\text { Median (25th-75th percentile) }\end{array}$ & $6.0(3.0-8.0)$ & $4.0(2.5-6.5)$ \\
\hline $\begin{array}{l}\text { Sleep quality (PSQI score): } \\
\text { Median (25th-75th percentile) }\end{array}$ & $4.0(2.3-8.8)$ & $5.0(4.0-9.3)$ \\
\hline Daytime sleepiness (ESS score): Median (25th-75th percentile)
\end{tabular}

There were no significant differences in metabolic parameters between DT and SW nurses (Table 2). DT nurses showed a higher median value of total cholesterol, but the difference was not significant. Other blood parameters, systolic/diastolic pressure, BMI, waist circumference, skin thickness, and body fat were also similar in the two groups. 
Table 2. Metabolic characteristics of daytime (DT) and shift-working (SW) nurses. Results are expressed as median (25th-75th percentile).

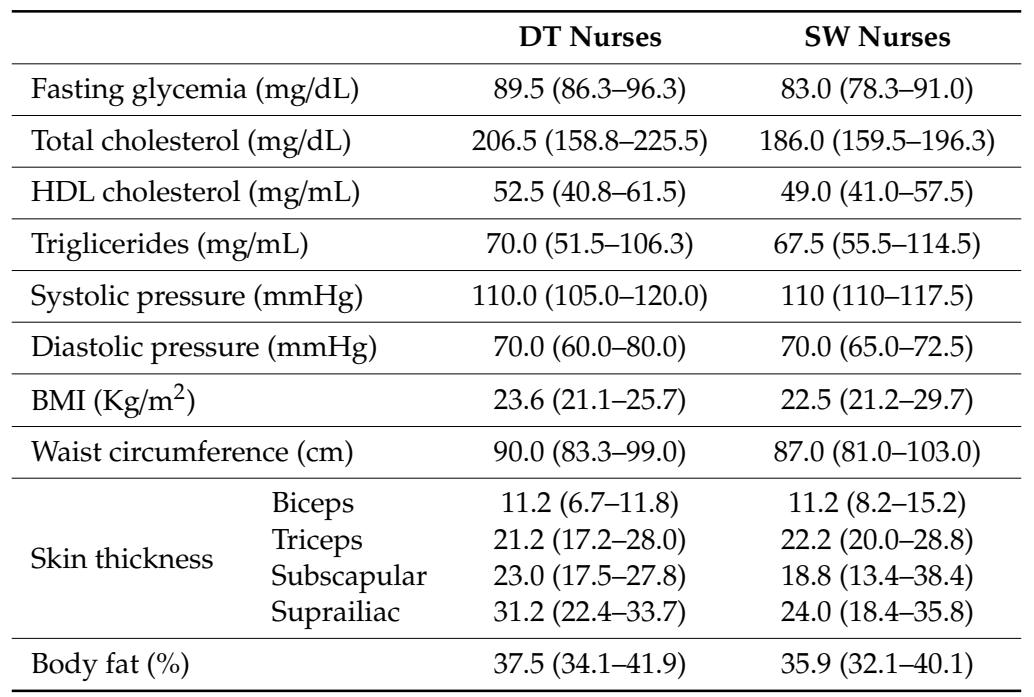

Data about total energy intake, diet composition, and total energy expenditure were similar in the two groups (Table 3). The statistical analysis did not show significant differences.

Table 3. Energy intake, diet composition, and total energy expenditure of daytime (DT) and shiftworking (SW) nurses. Results are expressed as median (25th-75th percentile).

\begin{tabular}{|c|c|c|c|}
\hline & & DT Nurses & SW Nurses \\
\hline \multicolumn{2}{|c|}{ Total Energy intake (Kcal) } & $2004(1712-2272)$ & $1927(1850-2112)$ \\
\hline \multirow{3}{*}{ Diet composition } & Carbohydrates (\%) & $55.0(53.2-55.5)$ & $55.0(53.9-55.4)$ \\
\hline & Proteins $(\%)$ & $18.4(17.8-19.4)$ & $19.0(18.6-19.6)$ \\
\hline & Fats $(\%)$ & $26.5(26.1-27.8)$ & $26.1(25.8-25.8)$ \\
\hline \multicolumn{2}{|c|}{ Total energy expenditure (Kcal) } & $2179(1866-2438)$ & $2225(1962-2527)$ \\
\hline \multicolumn{2}{|c|}{ Energy expenditure due to locomotor activity (Kcal) } & $874(694-1484)$ & $1050(923-1294)$ \\
\hline
\end{tabular}

Levels of miR-92a in serum exosomes are reported in Figure 1. We found significantly higher levels of miR-92a in DT nurses than in SW nurses [median 14.2 versus $4.3\left(2^{-\Delta \mathrm{Ct}} / 10^{3}\right), p=0.002$ ]. Since miR-92a in serum exosomes inversely correlate with BAT activity, results were indicative of a lower BAT activity in DT nurses compared with SW nurses.

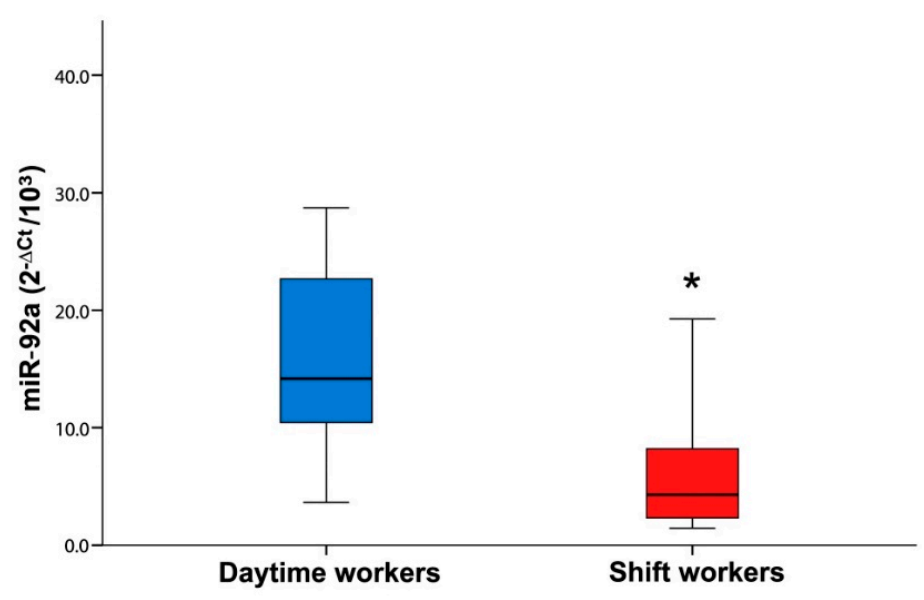

Figure 1. Box plot of levels of miR-92a in serum exosomes of daytime (DT) and shift-working (SW) nurses. ${ }^{*} p<0.05$, Mann-Whitney $\mathrm{U}$ test. 


\section{Discussion}

Shift work may disrupt sleep and meal rhythms. The perturbation of biological rhythms can alter metabolic homeostasis that may lead to weight gain and/or metabolic disturbances [54-57]. Shift work was associated with higher waist circumference [58-60], and a higher risk of metabolic syndrome and cardiovascular events [7,61-63]. In our sample, SW are similar to DT nurses concerning the waist circumference and the other metabolic parameters analyzed. The lack of differences is likely due to the small size effect that shift work has on metabolic parameters. A larger sampling would help this to be more visible. Moreover, our sample constituted of young nurses (median age of 39.0 years) with a median job seniority of 13.0 years. These parameters likely differ from the metabolic alterations shown in older shift workers [64]. Several authors have obtained increased BMI values in SW compared to DT workers $[60,65,66]$, which, however, were not found to be associated to differences in diet style $[65,67]$, nor in physical activity between the two groups of workers $[10,68,69]$. Other factors, such as a low level of active BAT, may also contribute to weight gain in SW.

This study measured the levels of miR-92a that a study of Chen and colleagues inversely correlated with BAT activity [39]. Contrary to the hypothesis that SW may have a low level of active BAT, we found lower levels of miR-92a in SW nurses compared to DT nurses, indicative of higher BAT activity [39]. Several argumentations may be possible: (1) The increased BAT activity detected in SW nurses may be a physiologic mechanism to counteract metabolic alterations induced by circadian disruption linked to shift work. This counteracting mechanism may be impaired after a long duration of shift work resulting in weight gain and metabolic syndrome. (2) In a study on mice, prolonged daily light exposure (similar to the experiences of shift workers during a night shift) decreases BAT activity [70]. However, mice differ from humans as they usually sleep during the day and are active and eat during the night, resulting in a possible opposite effect of light on BAT. (3) Shift work can induce a sympathodominant state [71]. Since the sympathetic nervous system is a stimulator of BAT [72], the higher BAT activity in SW nurses may be caused by a sympathetic stimulation. (4) Since BAT activity has a circadian rhythm [73,74], our finding may be related to a phase misalignment of a circadian cycle of BAT activity in SW compared to DT nurses. (5) Since the activity of BAT produces heat, its increased activity may be the cause of the higher peripheral skin temperature previously demonstrated in a similar sample of SW nurses [75]. (6) The lower levels of miR-92a found in the serum of shift workers may not only be related to BAT activity, but also to other biological processes [76,77].

This last hypothesis must be carefully considered. Further investigations are necessary due to the inverse correlation between serum exosomal miR-92a and BAT activity, which is based only on the study of Chen and colleagues [39]. Moreover, the miR-92a is involved in the regulation of several genes. MiRTargetLink [78], using information from miRTarBase [79,80], found 1419 genes that are targeted by miR-92a: 30 interactions with strong support, 1301 interactions with weak support, and 88 predicted interactions (Table S1). MiR-92a regulates several processes including cell proliferation and the development of cancer $[77,81]$. Night shift work has been suggested to be associated with the onset of cancer, specifically breast cancer [82-85]. Interestingly, in breast cancer the miR-92a is deregulated [86-92]. The miR-92a targets and downregulates estrogen receptor beta (ER $\beta)$, and is controlled by estrogen [93]. Since higher levels of estrogen were found in shift workers [94-97], miR-92a may contribute to the deregulation of estrogen levels induced by shift work. Hence, it would be interesting to perform additional investigations regarding the possible role of miR-92a related to a higher risk of breast cancer in shift workers.

\section{Conclusions}

The significant lower levels of serum exosomal miR-92a suggest a higher BAT activity in SW nurses compared to DT nurses. Additional studies using gold standard tests for BAT activity in shift workers are needed. The possibility that the lower levels of miR-92a found in the serum of shift workers may not only be related to BAT activity, but also to other factors cannot be ruled out. Considering that 
miR-92a takes part in several biological processes, including breast cancer, our results suggest further investigations on miR-92a in shift workers.

Supplementary Materials: The following are available online at http://www.mdpi.com/2076-3417/10/2/430/s1, Table S1: miRNA-target interaction network for miR-92a. The central node is the miR-92a, surrounded by validated targets with strong evidence (green), weak evidence (blue), and predicted targets (yellow). Targets are listed below the figure.

Author Contributions: Conceptualization, M.B.; methodology, M.B., M.E.Z., M.F.T., C.L., and V.R.; formal analysis, M.B., C.L., and V.R.; investigation, M.E.Z. and M.F.T.; writing_-original draft preparation, M.B., M.E.Z., and M.F.T.; writing - review and editing M.B. and L.S.; supervision, L.S.; project administration, M.B. and L.S.; funding acquisition, M.B. All authors have read and agreed to the published version of the manuscript.

Funding: This research was supported by the Polytechnic University of Marche, Ancona, Italy. This research received no external funding.

Acknowledgments: This research is dedicated to the memory of Alfredo Copertaro. We thank Saverio Cinti for the critical revision of the manuscript and Megan Conner, American writer and editor, for her assistance in revising our manuscript.

Conflicts of Interest: The authors declare no conflict of interest.

\section{References}

1. Boivin, D.B.; Boudreau, P. Impacts of shift work on sleep and circadian rhythms. Pathol. Biol. 2014, 62, 292-301. [CrossRef] [PubMed]

2. Copertaro, A.; Bracci, M. Working against the biological clock: A review for the occupational physician. Ind. Health 2019, 57, 557-569. [CrossRef] [PubMed]

3. Engin, A. Circadian rhythms in diet-induced obesity. Adv. Exp. Med. Biol. 2017, 960, 19-52. [PubMed]

4. McHill, A.W.; Wright, K.P., Jr. Role of sleep and circadian disruption on energy expenditure and in metabolic predisposition to human obesity and metabolic disease. Obes. Rev. 2017, 18 (Suppl.S1), 15-24. [CrossRef]

5. Bracci, M.; Copertaro, A.; Ciarapica, V.; Barbaresi, M.; Esposito, S.; Albanesi, A.; Valentino, M.; Ledda, C.; Rapisarda, V.; Santarelli, L. Nocturnin gene diurnal variation in healthy volunteers and expression levels in shift workers. BioMed Res. Int. 2019, 2019, 7582734. [CrossRef] [PubMed]

6. Lim, Y.C.; Hoe, V.C.W.; Darus, A.; Bhoo-Pathy, N. Association between night-shift work, sleep quality and metabolic syndrome. Occup. Environ. Med. 2018, 75, 716-723. [CrossRef]

7. Wang, F.; Zhang, L.; Zhang, Y.; Zhang, B.; He, Y.; Xie, S.; Li, M.; Miao, X.; Chan, E.Y.; Tang, J.L.; et al. Meta-analysis on night shift work and risk of metabolic syndrome. Obes. Rev. 2014, 15, 709-720. [CrossRef]

8. Esquirol, Y.; Perret, B.; Ruidavets, J.B.; Marquie, J.C.; Dienne, E.; Niezborala, M.; Ferrieres, J. Shift work and cardiovascular risk factors: New knowledge from the past decade. Arch. Cardiovasc.Dis. 2011, 104, 636-668. [CrossRef]

9. Puttonen, S.; Harma, M.; Hublin, C. Shift work and cardiovascular disease-Pathways from circadian stress to morbidity. Scand. J. Work Environ. Health 2010, 36, 96-108. [CrossRef]

10. Roskoden, F.C.; Kruger, J.; Vogt, L.J.; Gartner, S.; Hannich, H.J.; Steveling, A.; Lerch, M.M.; Aghdassi, A.A. Physical activity, energy expenditure, nutritional habits, quality of sleep and stress levels in shift-working health care personnel. PLoS ONE 2017, 12, e0169983. [CrossRef]

11. Cypess, A.M.; Lehman, S.; Williams, G.; Tal, I.; Rodman, D.; Goldfine, A.B.; Kuo, F.C.; Palmer, E.L.; Tseng, Y.H.; Doria, A.; et al. Identification and importance of brown adipose tissue in adult humans. N. Engl. J. Med. 2009, 360, 1509-1517. [CrossRef] [PubMed]

12. van Marken Lichtenbelt, W.D.; Vanhommerig, J.W.; Smulders, N.M.; Drossaerts, J.M.; Kemerink, G.J; Bouvy, N.D.; Schrauwen, P.; Teule, G.J. Cold-activated brown adipose tissue in healthy men. N. Engl. J. Med. 2009, 360, 1500-1508. [CrossRef] [PubMed]

13. Virtanen, K.A.; Lidell, M.E.; Orava, J.; Heglind, M.; Westergren, R.; Niemi, T.; Taittonen, M.; Laine, J.; Savisto, N.J.; Enerback, S.; et al. Functional brown adipose tissue in healthy adults. N. Engl. J. Med. 2009, 360, 1518-1525. [CrossRef] [PubMed]

14. Yoneshiro, T.; Matsushita, M.; Nakae, S.; Kameya, T.; Sugie, H.; Tanaka, S.; Saito, M. Brown adipose tissue is involved in the seasonal variation of cold-induced thermogenesis in humans. Am. J. Physiol. Regul. Integr. Comp. Physiol. 2016, 310, R999-R1009. [CrossRef] [PubMed] 
15. Giordano, A.; Frontini, A.; Cinti, S. Convertible visceral fat as a therapeutic target to curb obesity. Nat. Rev. Drug Discov. 2016, 15, 405-424. [CrossRef] [PubMed]

16. Cinti, S. Adipose organ development and remodeling. Compr. Physiol. 2018, 8, 1357-1431. [PubMed]

17. Cinti, S. Ucp1 protein: The molecular hub of adipose organ plasticity. Biochimie 2017, 134, 71-76. [CrossRef] [PubMed]

18. Fenzl, A.; Kiefer, F.W. Brown adipose tissue and thermogenesis. Horm. Mol. Biol. Clin. Investig. 2014, 19, 25-37. [CrossRef]

19. Kiefer, F.W. The significance of beige and brown fat in humans. Endocr. Connect. 2017, 6, R70-R79. [CrossRef]

20. Trajkovski, M.; Lodish, H. MicroRNA networks regulate development of brown adipocytes. Trends Endocrinol. Metab. 2013, 24, 442-450. [CrossRef]

21. Bartelt, A.; Bruns, O.T.; Reimer, R.; Hohenberg, H.; Ittrich, H.; Peldschus, K.; Kaul, M.G.; Tromsdorf, U.I.; Weller, H.; Waurisch, C.; et al. Brown adipose tissue activity controls triglyceride clearance. Nat. Med. 2011, 17, 200-205. [CrossRef] [PubMed]

22. Wang, Q.; Zhang, M.; Xu, M.; Gu, W.; Xi, Y.; Qi, L.; Li, B.; Wang, W. Brown adipose tissue activation is inversely related to central obesity and metabolic parameters in adult human. PLoS ONE 2015, 10, e0123795. [CrossRef] [PubMed]

23. Cinti, S. Anatomy and physiology of the nutritional system. Mol. Asp. Med. 2019, 68, 101-107. [CrossRef] [PubMed]

24. Cereijo, R.; Taxeras, S.D.; Piquer-Garcia, I.; Pellitero, S.; Martinez, E.; Tarasco, J.; Moreno, P.; Balibrea, J.; Puig-Domingo, M.; Jimenez-Pavon, D.; et al. Elevated levels of circulating miR-92a are associated with impaired glucose homeostasis in patients with obesity and correlate with metabolic status after bariatric surgery. Obes. Surg. 2019. [CrossRef] [PubMed]

25. Saito, M.; Okamatsu-Ogura, Y.; Matsushita, M.; Watanabe, K.; Yoneshiro, T.; Nio-Kobayashi, J.; Iwanaga, T.; Miyagawa, M.; Kameya, T.; Nakada, K.; et al. High incidence of metabolically active brown adipose tissue in healthy adult humans: Effects of cold exposure and adiposity. Diabetes 2009, 58, 1526-1531. [CrossRef] [PubMed]

26. Mello, C.C.; Conte, D., Jr. Revealing the world of RNA interference. Nature 2004, 431, 338-342. [CrossRef]

27. Pfeifer, A.; Lehmann, H. Pharmacological potential of RNAi-Focus on miRNA. Pharmacol. Ther. 2010, 126, 217-227. [CrossRef]

28. Meister, G.; Tuschl, T. Mechanisms of gene silencing by double-stranded RNA. Nature 2004, 431, 343-349. [CrossRef]

29. Rong, X.; Jia, L.; Hong, L.; Pan, L.; Xue, X.; Zhang, C.; Lu, J.; Jin, Z.; Qiu, H.; Wu, R.; et al. Serum mir-92a-3p as a new potential biomarker for diagnosis of Kawasaki disease with coronary artery lesions. J. Cardiovasc. Transl. Res. 2017, 10, 1-8. [CrossRef]

30. Raposo, G.; Stoorvogel, W. Extracellular vesicles: Exosomes, microvesicles, and friends. J. Cell Biol. 2013, 200, 373-383. [CrossRef]

31. Yamamoto, T.; Kosaka, N.; Ochiya, T. Latest advances in extracellular vesicles: From bench to bedside. Sci. Technol. Adv. Mater. 2019, 20, 746-757. [CrossRef] [PubMed]

32. Wang, M.; Yu, F.; Ding, H.; Wang, Y.; Li, P.; Wang, K. Emerging function and clinical values of exosomal micrornas in cancer. Mol. Ther. Nucleic. Acids 2019, 16, 791-804. [CrossRef] [PubMed]

33. Zhang, J.; Li, S.; Li, L.; Li, M.; Guo, C.; Yao, J.; Mi, S. Exosome and exosomal microRNA: Trafficking, sorting, and function. Genom. Proteom. Bioinform. 2015, 13, 17-24. [CrossRef] [PubMed]

34. Mitchell, P.S.; Parkin, R.K.; Kroh, E.M.; Fritz, B.R.; Wyman, S.K.; Pogosova-Agadjanyan, E.L.; Peterson, A.; Noteboom, J.; O’Briant, K.C.; Allen, A.; et al. Circulating microRNAs as stable blood-based markers for cancer detection. Proc. Natl. Acad. Sci. USA 2008, 105, 10513-10518. [CrossRef] [PubMed]

35. Huang, W. MicroRNAs: Biomarkers, diagnostics, and therapeutics. Methods Mol. Biol. 2017, 1617, 57-67. [PubMed]

36. Engin, A.B. MicroRNA and adipogenesis. Adv. Exp. Med. Biol. 2017, 960, 489-509. [PubMed]

37. Loh, W.P.; Yang, Y.; Lam, K.P. MiR-92a enhances recombinant protein productivity in CHO cells by increasing intracellular cholesterol levels. Biotechnol. J. 2017, 12, 1600488. [CrossRef]

38. Huang, Y.; Tang, S.; Ji-Yan, C.; Huang, C.; Li, J.; Cai, A.P.; Feng, Y.Q. Circulating miR-92a expression level in patients with essential hypertension: A potential marker of atherosclerosis. J. Hum. Hypertens. 2017, 31, 200-205. [CrossRef] 
39. Chen, Y.; Buyel, J.J.; Hanssen, M.J.; Siegel, F.; Pan, R.; Naumann, J.; Schell, M.; van der Lans, A.; Schlein, C.; Froehlich, H.; et al. Exosomal microrna miR-92a concentration in serum reflects human brown fat activity. Nat. Commun. 2016, 7, 11420. [CrossRef]

40. Horne, J.A.; Ostberg, O. A self-assessment questionnaire to determine morningness-eveningness in human circadian rhythms. Int. J. Chronobiol. 1976, 4, 97-110. [PubMed]

41. Bracci, M.; Ciarapica, V.; Zabaleta, M.E.; Tartaglione, M.F.; Pirozzi, S.; Giuliani, L.; Piva, F.; Valentino, M.; Ledda, C.; Rapisarda, V.; et al. BRCA1 and BRCA2 gene expression: Diurnal variability and influence of shift work. Cancers 2019, 11, 1146. [CrossRef] [PubMed]

42. Randler, C.; Engelke, J. Gender differences in chronotype diminish with age: A meta-analysis based on morningness/chronotype questionnaires. Chronobiol. Int. 2019, 36, 888-905. [CrossRef] [PubMed]

43. Razavi, P.; Devore, E.E.; Bajaj, A.; Lockley, S.W.; Figueiro, M.G.; Ricchiuti, V.; Gauderman, W.J.; Hankinson, S.E.; Willett, W.C.; Schernhammer, E.S. Shift work, chronotype, and melatonin rhythm in nurses. Cancer Epidemiol.Biomark. Prev. 2019, 28, 1177-1186. [CrossRef] [PubMed]

44. Taillard, J.; Philip, P.; Chastang, J.F.; Bioulac, B. Validation of Horne and Ostberg morningness-eveningness questionnaire in a middle-aged population of French workers. J. Biol. Rhythms 2004, 19, 76-86. [CrossRef] [PubMed]

45. Buysse, D.J.; Reynolds, C.F., III; Monk, T.H.; Berman, S.R.; Kupfer, D.J. The Pittsburgh Sleep Quality index: A new instrument for psychiatric practice and research. Psychiatry Res. 1989, 28, 193-213. [CrossRef]

46. Johns, M.W. A new method for measuring daytime sleepiness: The Epworth sleepiness scale. Sleep 1991, 14, 540-545. [CrossRef]

47. Vignatelli, L.; Plazzi, G.; Barbato, A.; Ferini-Strambi, L.; Manni, R.; Pompei, F.; D’Alessandro, R. Italian version of the Epworth sleepiness scale: External validity. Neurol. Sci 2003, 23, 295-300. [CrossRef]

48. Durnin, J.V.; Womersley, J. Body fat assessed from total body density and its estimation from skinfold thickness: Measurements on 481 men and women aged from 16 to 72 years. Br. J. Nutr. 1974, 32, 77-97. [CrossRef]

49. Salvini, S.; Gnagnarella, P.; Parpinel, M.T.; Boyle, P.; Decarli, A.; Ferraroni, M.; Giacosa, A.; La Vecchia, C.; Negri, E.; Franceschi, S. The food composition database for an italian food frequency questionnaire. J. Food Compos. Anal. 1996, 9, 57-71. [CrossRef]

50. Manns, P.J.; Haennel, R.G. Sensewear armband and stroke: Validity of energy expenditure and step count measurement during walking. Stroke Res. Treat. 2012, 2012, 247165. [CrossRef]

51. Tomasetti, M.; Staffolani, S.; Nocchi, L.; Neuzil, J.; Strafella, E.; Manzella, N.; Mariotti, L.; Bracci, M.; Valentino, M.; Amati, M.; et al. Clinical significance of circulating miR-126 quantification in malignant mesothelioma patients. Clin. Biochem. 2012, 45, 575-581. [CrossRef] [PubMed]

52. Schmittgen, T.D.; Livak, K.J. Analyzing real-time PCR data by the comparative C(T) method. Nat. Protoc. 2008, 3, 1101-1108. [CrossRef] [PubMed]

53. Sourvinou, I.S.; Markou, A.; Lianidou, E.S. Quantification of circulating miRNAs in plasma: Effect of preanalytical and analytical parameters on their isolation and stability. J. Mol. Diagn. 2013, 15, 827-834. [CrossRef] [PubMed]

54. Ledda, C.; Cina, D.; Matera, S.; Mucci, N.; Bracci, M.; Rapisarda, V. High HOMA-IR index in healthcare shift workers. Medicina 2019, 55, 186. [CrossRef] [PubMed]

55. Strohmaier, S.; Devore, E.E.; Zhang, Y.; Schernhammer, E.S. A review of data of findings on night shift work and the development of DM and CVD events: A synthesis of the proposed molecular mechanisms. Curr. Diab. Rep. 2018, 18, 132. [CrossRef]

56. Vetter, C.; Dashti, H.S.; Lane, J.M.; Anderson, S.G.; Schernhammer, E.S.; Rutter, M.K.; Saxena, R.; Scheer, F. Night shift work, genetic risk, and type 2 diabetes in the UK Biobank. Diabetes Care 2018, 41, 762-769. [CrossRef]

57. Kolbe, I.; Oster, H. Chronodisruption, metabolic homeostasis, and the regulation of inflammation in adipose tissues. Yale J. Biol. Med. 2019, 92, 317-325. [PubMed]

58. Copertaro, A.; Bracci, M.; Barbaresi, M.; Santarelli, L. Role of waist circumference in the diagnosis of metabolic syndrome and assessment of cardiovascular risk in shift workers. Med. Lav. 2008, 99, 444-453. [PubMed]

59. Copertaro, A.; Bracci, M.; Barbaresi, M.; Santarelli, L. Assessment of cardiovascular risk in shift healthcare workers. Eur. J. Cardiovasc. Prev. Rehabil. 2008, 15, 224-229. [CrossRef]

60. Peplonska, B.; Bukowska, A.; Sobala, W. Association of rotating night shift work with BMI and abdominal obesity among nurses and midwives. PLoS ONE 2015, 10, e0133761. [CrossRef] 
61. Thosar, S.S.; Butler, M.P.; Shea, S.A. Role of the circadian system in cardiovascular disease. J. Clin. Investig. 2018, 128, 2157-2167. [CrossRef] [PubMed]

62. Torquati, L.; Mielke, G.I.; Brown, W.J.; Kolbe-Alexander, T. Shift work and the risk of cardiovascular disease. A systematic review and meta-analysis including dose-response relationship. Scand. J. Work Environ. Health 2018, 44, 229-238. [CrossRef] [PubMed]

63. Rosa, D.; Terzoni, S.; Dellafiore, F.; Destrebecq, A. Systematic review of shift work and nurses' health. Occup. Med. 2019, 69, 237-243. [CrossRef] [PubMed]

64. Roomi, M.A.; Mohammadnezhad, M. Prevalence of metabolic syndrome among apparently healthy workforce. J. Ayub Med. Coll. Abbottabad 2019, 31, 252-254. [PubMed]

65. Croce, N.; Bracci, M.; Ceccarelli, G.; Barbadoro, P.; Prospero, E.; Santarellia, L. Body mass index in shift workers: Relation to diet and physical activity. G. Ital. Med. Lav. Ergon. 2007, 29, 488-489. [PubMed]

66. Proper, K.I.; van de Langenberg, D.; Rodenburg, W.; Vermeulen, R.C.H.; van der Beek, A.J.; van Steeg, H.; van Kerkhof, L.W.M. The relationship between shift work and metabolic risk factors: A systematic review of longitudinal studies. Am. J. Prev. Med. 2016, 50, e147-e157. [CrossRef] [PubMed]

67. Barbadoro, P.; Santarelli, L.; Croce, N.; Bracci, M.; Vincitorio, D.; Prospero, E.; Minelli, A. Rotating shift-work as an independent risk factor for overweight italian workers: A cross-sectional study. PLoS ONE 2013, 8, e63289. [CrossRef]

68. Hulsegge, G.; Gupta, N.; Holtermann, A.; Jorgensen, M.B.; Proper, K.I.; van der Beek, A.J. Shift workers have similar leisure-time physical activity levels as day workers but are more sedentary at work. Scand. J. Work Environ. Health 2017, 43, 127-135. [CrossRef]

69. Loef, B.; Hulsegge, G.; Wendel-Vos, G.C.; Verschuren, W.M.; Vermeulen, R.C.; Bakker, M.F.; van der Beek, A.J.; Proper, K.I. Non-occupational physical activity levels of shift workers compared with non-shift workers. Occup. Environ. Med. 2017, 74, 328-335. [CrossRef]

70. Kooijman, S.; van den Berg, R.; Ramkisoensing, A.; Boon, M.R.; Kuipers, E.N.; Loef, M.; Zonneveld, T.C.; Lucassen, E.A.; Sips, H.C.; Chatzispyrou, I.A.; et al. Prolonged daily light exposure increases body fat mass through attenuation of brown adipose tissue activity. Proc. Natl. Acad. Sci. USA 2015, 112, 6748-6753. [CrossRef]

71. Ishii, N.; Iwata, T.; Dakeishi, M.; Murata, K. Effects of shift work on autonomic and neuromotor functions in female nurses. J. Occup. Health 2004, 46, 352-358. [CrossRef] [PubMed]

72. Bartness, T.J.; Vaughan, C.H.; Song, C.K. Sympathetic and sensory innervation of brown adipose tissue. Int. J. Obes. 2010, 34 (Suppl. S1), S36-S42. [CrossRef]

73. Lee, P.; Bova, R.; Schofield, L.; Bryant, W.; Dieckmann, W.; Slattery, A.; Govendir, M.A.; Emmett, L.; Greenfield, J.R. Brown adipose tissue exhibits a glucose-responsive thermogenic biorhythm in humans. Cell Metab. 2016, 23, 602-609. [CrossRef]

74. Onder, Y.; Green, C.B. Rhythms of metabolism in adipose tissue and mitochondria. Neurobiol. Sleep Circadian Rhythms 2018, 4, 57-63. [CrossRef] [PubMed]

75. Bracci, M.; Ciarapica, V.; Copertaro, A.; Barbaresi, M.; Manzella, N.; Tomasetti, M.; Gaetani, S.; Monaco, F.; Amati, M.; Valentino, M.; et al. Peripheral skin temperature and circadian biological clock in shift nurses after a day off. Int. J. Mol. Sci. 2016, 17, 623. [CrossRef] [PubMed]

76. Giral, H.; Kratzer, A.; Landmesser, U. MicroRNAs in lipid metabolism and atherosclerosis. Best Pract. Res. Clin. Endocrinol. Metab. 2016, 30, 665-676. [CrossRef] [PubMed]

77. Li, M.; Guan, X.; Sun, Y.; Mi, J.; Shu, X.; Liu, F.; Li, C. MiR-92a family and their target genes in tumorigenesis and metastasis. Exp. Cell Res. 2014, 323, 1-6. [CrossRef] [PubMed]

78. MiRTargetLink Human. Available online: https://ccb-web.cs.uni-saarland.de/mirtargetlink/ (accessed on 26 December 2019).

79. Chou, C.H.; Chang, N.W.; Shrestha, S.; Hsu, S.D.; Lin, Y.L.; Lee, W.H.; Yang, C.D.; Hong, H.C.; Wei, T.Y.; Tu, S.J.; et al. MiRTarBase 2016: Updates to the experimentally validated miRNA-target interactions database. Nucleic Acids Res. 2016, 44, D239-D247. [CrossRef] [PubMed]

80. Hamberg, M.; Backes, C.; Fehlmann, T.; Hart, M.; Meder, B.; Meese, E.; Keller, A. MiRTargetLink-miRNAs, genes and interaction networks. Int. J. Mol. Sci. 2016, 17, 564. [CrossRef]

81. Manni, I.; Artuso, S.; Careccia, S.; Rizzo, M.G.; Baserga, R.; Piaggio, G.; Sacchi, A. The microRNA miR-92 increases proliferation of myeloid cells and by targeting p63 modulates the abundance of its isoforms. FASEB J. 2009, 23, 3957-3966. [CrossRef] 
82. Wegrzyn, L.R.; Tamimi, R.M.; Rosner, B.A.; Brown, S.B.; Stevens, R.G.; Eliassen, A.H.; Laden, F.; Willett, W.C.; Hankinson, S.E.; Schernhammer, E.S. Rotating night-shift work and the risk of breast cancer in the nurses' health studies. Am. J. Epidemiol. 2017, 186, 532-540. [CrossRef] [PubMed]

83. Ward, E.M.; Germolec, D.; Kogevinas, M.; McCormick, D.; Vermeulen, R.; Anisimov, V.N.; Aronson, K.J.; Bhatti, P.; Cocco, P.; Costa, G.; et al. Carcinogenicity of night shift work. Lancet Oncol. 2019, 20, 1058-1059. [CrossRef]

84. Hansen, J. Night shift work and risk of breast cancer. Curr. Environ. Health Rep. 2017, 4, 325-339. [CrossRef] [PubMed]

85. Lunn, R.M.; Blask, D.E.; Coogan, A.N.; Figueiro, M.G.; Gorman, M.R.; Hall, J.E.; Hansen, J.; Nelson, R.J.; Panda, S.; Smolensky, M.H.; et al. Health consequences of electric lighting practices in the modern world: A report on the national toxicology program's workshop on shift work at night, artificial light at night, and circadian disruption. Sci. Total Environ. 2017, 607-608, 1073-1084. [CrossRef] [PubMed]

86. Cun, J.; Yang, Q. Bioinformatics-based interaction analysis of miR-92a-3p and key genes in tamoxifen-resistant breast cancer cells. Biomed. Pharmacother. 2018, 107, 117-128. [CrossRef] [PubMed]

87. Danza, K.; De Summa, S.; Pinto, R.; Pilato, B.; Palumbo, O.; Carella, M.; Popescu, O.; Digennaro, M.; Lacalamita, R.; Tommasi, S. TGFbeta and miRNA regulation in familial and sporadic breast cancer. Oncotarget 2017, 8, 50715-50723. [CrossRef]

88. Li, M.; Zhou, Y.; Xia, T.; Zhou, X.; Huang, Z.; Zhang, H.; Zhu, W.; Ding, Q.; Wang, S. Circulating microRNAs from the mir-106a-363 cluster on chromosome $X$ as novel diagnostic biomarkers for breast cancer. Breast Cancer Res. Treat. 2018, 170, 257-270. [CrossRef]

89. Nilsson, S.; Moller, C.; Jirstrom, K.; Lee, A.; Busch, S.; Lamb, R.; Landberg, G. Downregulation of miR-92a is associated with aggressive breast cancer features and increased tumour macrophage infiltration. PLOS ONE 2012, 7, e36051. [CrossRef]

90. Ou, Z.; Wang, Y.; Chen, J.; Tao, L.; Zuo, L.; Sahasrabudhe, D.; Joseph, J.; Wang, L.; Yeh, S. Estrogen receptor beta promotes bladder cancer growth and invasion via alteration of miR-92a/DAB2IP signals. Exp. Mol. Med. 2018, 50, 152. [CrossRef]

91. Pillai, M.M.; Gillen, A.E.; Yamamoto, T.M.; Kline, E.; Brown, J.; Flory, K.; Hesselberth, J.R.; Kabos, P. HITS-CLIP reveals key regulators of nuclear receptor signaling in breast cancer. Breast Cancer Res. Treat. 2014, 146, 85-97. [CrossRef]

92. Si, H.; Sun, X.; Chen, Y.; Cao, Y.; Chen, S.; Wang, H.; Hu, C. Circulating microRNA-92a and microRNA-21 as novel minimally invasive biomarkers for primary breast cancer. J. Cancer Res. Clin. Oncol. 2013, 139, $223-229$. [CrossRef] [PubMed]

93. Al-Nakhle, H.; Burns, P.A.; Cummings, M.; Hanby, A.M.; Hughes, T.A.; Satheesha, S.; Shaaban, A.M.; Smith, L.; Speirs, V. Estrogen receptor \{beta\}1 expression is regulated by miR-92 in breast cancer. Cancer Res. 2010, 70, 4778-4784. [CrossRef] [PubMed]

94. Bracci, M.; Copertaro, A.; Manzella, N.; Staffolani, S.; Strafella, E.; Nocchi, L.; Barbaresi, M.; Copertaro, B.; Rapisarda, V.; Valentino, M.; et al. Influence of night-shift and napping at work on urinary melatonin, 17-beta-estradiol and clock gene expression in pre-menopausal nurses. J. Biol. Regul. Homeost. Agents 2013, 27, 267-274. [PubMed]

95. Bracci, M.; Manzella, N.; Copertaro, A.; Staffolani, S.; Strafella, E.; Barbaresi, M.; Copertaro, B.; Rapisarda, V.; Valentino, M.; Santarelli, L. Rotating-shift nurses after a day off: Peripheral clock gene expression, urinary melatonin, and serum 17-beta-estradiol levels. Scand. J. Work Environ. Health 2014, 40, 295-304. [CrossRef] [PubMed]

96. Peplonska, B.; Bukowska, A.; Lie, J.A.; Gromadzinska, J.; Zienolddiny, S. Night shift work and other determinants of estradiol, testosterone, and dehydroepiandrosterone sulfate among middle-aged nurses and midwives. Scand. J. Work Environ. Health 2016, 42, 435-446. [CrossRef] [PubMed]

97. Schernhammer, E.S.; Rosner, B.; Willett, W.C.; Laden, F.; Colditz, G.A.; Hankinson, S.E. Epidemiology of urinary melatonin in women and its relation to other hormones and night work. Cancer Epidemiol. Biomark. Prev. 2004, 13, 936-943. [PubMed]

(C) 2020 by the authors. Licensee MDPI, Basel, Switzerland. This article is an open access article distributed under the terms and conditions of the Creative Commons Attribution (CC BY) license (http://creativecommons.org/licenses/by/4.0/). 